\title{
The Church in the Mural Art of Nobatia
}

\author{
Hind Salah El-Din Somida Awad \\ Faculty of Archaeology- Cairo University \\ aveagia417138@gmail.com
}

\begin{abstract}
:
The Church is simply known as "the body of Christ" (Ephesus 1:22-23) constituted by "the believers" (Acts 20:28; I Timothy 3:15; Ezra 5:8). The aim of this article is to investigate the concept of Church in Nobatia and its main particularities through mural art and architecture during the early Christian and Medieval ages of Nubia, for though the Church had contained the main requirements for the Christian worship which mainly coincided with the faith of the Orthodox Church, but one noticed the appearance of new themes in the Church of Sonqi Tino and Faras Cathedral in certain architectural locations in order to declare specific theological and political ideas, these new changes could therefore have influenced the faith of the Church of Nobatia, thence shedding additional light on them could reveal their origins and the reasons for their appearance as well as could give further insight for understanding the Church especially on that ambiguous part of the Christian history of not only Nobatia but also of Nubia in a whole.
\end{abstract}

\section{Keywords}

Church, Nubia, Nobatia, Faras, Sonqi Tino, Christ, Archangel Michael, Miaphysite

\section{Introduction}

According to the Church history of John of Ephesus 507-586 AD Nubia was converted to Christianity in the sixth century AD where the work of evangelization had begun through the Miaphysite (Eastern Orthodox Faith) Clergies when Julian the priest was sent from Constantinople by the Empress Theodora the Miaphysite wife of Emperor 


\section{JOURNAL OF THE FACULTY OF ARCHAEOLOGY -VOLUME 24 -2021}

Justinian I in $543 \mathrm{AD}$, he was accompanied by Theodoros the Miaphysite bishop of Philae. The work was completed by Longinus another Miaphysite, also from Byzantium, he arrived Nubia probably around 569 AD. Thence Christianity proceeded on the country where from the end of the sixth century it became mostly Christian. Indeed Nubia was evangelized from Egypt since many Egyptian hermits and tradesmen could have conducted Christian missionaries even earlier, however this did not support in creating a sizable Christian communities. As well, though there were also some Melkite activities especially from the Melkite Emperor Justinian I (527- 565 AD) who tried to overcome the missionary work of his wife Theodora and convert Nubia to his Byzantine or Melkite faith but indeed the efforts of the Miaphysites had triumphed at the end, at least in Nobatia (Adams, 1991a; Grossmann,1991a; McGuckin, 2004).

The oldest Church buildings from the sixth century $\mathrm{AD}$ have been found in the main towns of Nubia; Faras, the capital of Nobatia, and Old Dongola, capital of Makouria, as well as the fortress of Qasr Ibrim (Figure 1 Martens-Czarnecka, 2015). The Church architecture resembled to a great extent that of the Orthodox Church of Egypt where the basilica was considered the main type (Grossmann, 1991a). Thus the focus of this article is to seek the concept of Church in Nobatia and investigate its changes that were manifested through mural art and architecture for in fact the Christian faith there proved to swing sometimes between the Orthodox faith and the Melkite one especially during the Early Christian period and Medieval ages of Nobatia.

\section{The Church in the Mural Art of Nobatia}

Mural art played a significant role in the Christian history of Nubia; it was not purely of Egyptian style for it displayed some particularities from Palestine, Syria, and Byzantium, however, at the same time it expressed an indigenous touch added by the dark features in the portrayal of native rulers and bishops. Moreover, it does not seem to have had a specific fixed program, but, similar figures occurred in the same architectural location in a large number of Churches, where a new Christian artistic style appeared at 
the beginning of the eighth century $\mathrm{AD}$ in the form of bright colored wall paintings similar to those found in early Christian churches of Egypt; these were found especially at Faras and 'Abd al-Qadir' in Nobatia (Adams, 1991a; Adams, 1991b).

Church architecture of Nobatia contained the main requirements for the Christian worship which fundamentally were the area of the sanctuary, with its side chambers and the altar as the central place of the liturgy, as well as the nave with its several aisles prepared for the laity (Grossmann, 1991b; Obluski, 2016; Obluski, 2019). The spiritual role of the Church followed the meaning of the Christian Church to a great extent, where the Nave or the main body of the Church was designated to be as a Ship that gather human souls in their worldliness journey to take them safely to their eternal harbor, a meaning testified from the Ark of Noah during the Flood (1 Peter 3:20-21), as well when Jesus Christ was protecting Peter's boat and the apostles on the stormy Sea of Galilee (Mark 4:35-41), and when Clement of Alexandria approved the ship as a sign for the Church "And let our seals be either a dove, or a fish, or a ship scudding before the wind" (Paedagogus, III). Thence the Nave in the Church of Nobatia contained various iconographic programs to illustrate the believers constituting the body of the Christ i.e. the "Liturgical program" and the "Official program" (ZieliŃska, 2012).

With regard to the Pastophoria, as an architectural element -not only in the Church of Nobatia but also in many others at Nubia- it was built up to give way to a more sacred path for souls from the Nave, where the mural art of the northern Pastophorion was connected with the consecration of wine by Christ, a type of iconography as far as known of Nubian origin connected with the Liturgy of the Presanctified Gifts, while the southern Pastophorion functioned mainly as a Baptistery where frequently Saint John the Baptist and Saint Stephen the deacon were depicted.

Finally the Apse i.e. the more sacred part in the sanctuary of the Christian Church where God is presented in his majesty, it mainly displayed the "Two Zones" decoration with the representation of the "Enthroned Christ" in the upper part and the Virgin Mary 
surrounded by the Apostles in the lower one (ZieliŃska, 2012; Łajtar and Zielińska, 2016).

Indeed, though the iconographic system of the Church in Nobatia as well as its architecture were following the traditional ways of the architectural building and theological meanings in most of its parts that mainly accords with the Orthodox faith but one noticed two significant changes connected with the concept of the Church; the first was found in the Nave of the Church of Sonqi Tino (Figure 2), on the eastern wall of the southern aisle - now preserved in the Khartoum museum and dates back to the tenth century AD- where the Archangel Michael was strangely depicted with the four living beings; The lion touches his clothing, the man and the small hand of the missing bull hold the Sfaira, and the eagle is carrying the Crozier, while he was protecting a Nubian royal person in the place of the enthroned Christ (Figure 3 Helm, 1985) (Donadoni, 1975; Helm, 1985; Adam and Grzegorz, 2017; Salah El-Din, 2018).

The second one was found in Faras Cathedral (Figures 4, 5) most probably in its second phase of the 10th century AD where the king appeared in the "Two Zones" apse of the Church, specifically in the central place of the lower register just below the Virgin Mary who appeared touching his shoulders in a gesture of protection while the twelve Apostles were illustrated surrounding him (Figure 6 ZieliŃska, 2014). It is noteworthy that this theme had found its way also -but with some variations- in other Nubian churches through the course of 13th and the 14th centuries, like for example those from Dongola and Banganarti (Michalowski, 1966; Michalowski and Gerster, 1967; Vantini, 1970; Michalowski, 1974; Martens- Czarnecka, 2007; ZieliŃska, 2014).

In fact, these two changes in the traditional themes of the iconographic program appeared in Nobatia and their location within the architecture of the Church are worth to be investigated as they were connected directly with the concept of Church herself and apparently created a kind of interrelationship between mural painted decoration and architecture. The first one i.e. the identification between the archangel Michael and Christ 
that appeared in the Church of Sonqi Tino, it had a location related directly to the holy sanctuary zone that consequently implies a kind of deviation in the essence of the Orthodox faith and in turn in the spiritual path of the Church.

Indeed this identification between the archangel Michael and Christ had appeared since the fourth century $\mathrm{AD}$ as a response to the Arian-Nicene Conflict since the time of Constantine the Great (324 - 337AD) when he identified himself with Michael/ Christ/Logos and Sophia and thus became for that reason the image of God on earth who was responsible to protect the unity of the church and the Roman empire as well from the sequences of the victory of the Nicene Creed 325 AD over its Arian rival. Henceforth Michael gained an imperial patronage by those who proclaimed themselves to be the "New Constantine", like especially Justinian I (527-565 AD) and Basil I (867- 886 AD) (Tycner-Wolicka, 2013). Therefore, Justinian I for example in the sixth century not only gave the Archangel Michael a significant patronage but also exerted many efforts through Egypt in order to Christianize the kingdoms of Nubia to his Chalcedonian faith and beliefs aiming to succeed over his Miaphysite wife Theodora who also tried to convert especially Nobatia for her faith (Vasiliev, 1952; Martens- Czarnecka, 2015).

It is worth to mention in this point also that new sources-although few in numberappeared from Egypt to confirm this concept of identification between Michael and Christ, for example, in a Coptic letter written on an ostracon from the Coptic museum in Cairo and dated back to the end of the sixth and beginning of the seventh centuries $\mathrm{AD}$ a bishop asked for a change in a usual destination among some monks from the north to the south in order to fulfill the wish of the Archangel Michael (Salah El-Din, 2018). As well a newly discovered fragment was brought to my attention. This is a leaf written in Coptic script also speaks of worshippers of the Archangel Michael on which the text labels them as Non-Christians (Stewart, 2015). 


\section{JOURNAL OF THE FACULTY OF ARCHAEOLOGY -VOLUME 24 -2021}

The Archangel Michael, thence, gained a popular cult in Christian Nubia attested in both art and literature (Tsakos, 2016), especially worth to be noted the pseudoChrysostomic fragment found in Qasr Ibrim, where Michael was described with the symbols of his victory over Lucifer accompanied with the four living beings (Donadoni, 1975; Helm, 1985).

The second theme that concerns with portraying the king in the Apse of the Faras Cathedral and its continuity in other Churches of Nubia onward, in fact this iconographic theme was familiar in Byzantine art though in the area of the sanctuary was extremely rare. Thus, it could be therefore an apparent manifestation for a new theological and political meaning of the royal ideology within the iconographical program of the Nubian churches i.e. the king is portrayed now in the most sacred architectural part of the Church with God and Virgin Mary as well as Apostles and saints i.e. the king was chosen and supported from God, an idea considered strange for the spiritual role and concept of the Christian Church in general.

Thus, according to these two themes illustrated during the tenth century AD only until now - as far as I know- in the mural art of the Church of Sonqi Tino and Faras Cathedral respectively, one could suppose that the Christian Faith have witnessed some unusual changes at that time. As well, though they both looks like as if they were distinct from each other but one could deduce that they both had shared a connection which enabled them to appear in the mural art of the two Churches.

Trying to seek out this connection one found that it was mainly derived from the same source i.e. the Byzantine Empire or the Melkite faith; for the identification between the Archangel Michael and Christ was of Byzantine origin though appeared much earlier since the emperor Constantine the Great in the fourth century AD but the emperor Justinian I who commissioned missionaries to convert Nubia and especially Nobatia to his Melkite faith was among those emperors who proclaimed themselves as the "New Constantine" and thus adopted the way of Constantine the Great in giving the Archangel 
Michael an imperial patronage during his reign where the idea of the identification between Michael and Christ had penetrated the Byzantine societies to a great extent. As well although the second theme of portraying royal Kings was familiar in the Christian Byzantine art -as stated above- but in the area of the sanctuary it was extremely rare, one noticed that the most famous example for this rare portrayal was that also of the Melkite emperor Justinian I, he appeared with his attendants in the Apse of the San Vitale Church in Ravenna as a donor and believer (Figure 7) (ZieliŃska, 2014).

Therefore, Justinian I had held many features that proved tentatively his ownership to this connection between the two themes or changes illustrated in the Church of Sonqi Tino and Faras Cathedral, where one could deduce that the Melkite pulse adopted by him since the sixth century $\mathrm{AD}$ especially in Nobatia was still alive and even extended through its the Medieval ages.

Thence, at the end, one hopes that more researches and studies could be done on the art and architecture of the Nubian Church in Nobatia for they proved to hold many clues for the early Christian and Medieval history not only of Nobatia but also for the Church of Nubia in general. There still indeed many features and peculiarities of the Nubian Church that needs more investigation especially that of the evolution of the Christian faith and its swinging between the Orthodox and the Melkite beliefs whence mural art and architecture were utilized to express certain theological and political particularities arose in some periods of the early Christian and Medieval ages of Nubia.

\section{Conclusion}

This article aimed to seek the concept of Church in Nobatia as well as to trace its theological beliefs through mural art and architecture especially during the early Christian and Medieval ages of Nubia.

Indeed Church architecture and painted decoration of Nobatia contained the main requirements for the Christian worship that mainly coincided with the Orthodox Church, 


\section{JOURNAL OF THE FACULTY OF ARCHAEOLOGY -VOLUME 24 -2021}

but one noticed two specific changes; the first one was found in the Nave of the Church of Sonqi Tino on which the Archangel Michael was depicted with the four living beings in the place of the enthroned Christ and the second one was found in Faras Cathedral illustrating the king in the central place of the lower register of the Apse just below the Virgin Mary who was touching his shoulders in a gesture of protection.

In fact, these two new themes and their location within the architecture of the Church were directly connected with the concept of the Church herself where one deduced that mural art and architecture of the Christian Church of Nobatia were utilized at some time in the tenth century $\mathrm{AD}$ to express certain theological beliefs -and sometimes political - arose within the early Christian history of Nobatia.

Therefore one observed that the Church of Nobatia was influenced sometimes by the Melkite faith of the Byzantine Emperors especially Justinian I, who believed in the identification between the Archangel Michael and Christ, as well whom again the Nubian Church not only in Nobatia but also in many Churches of Nubia followed him partially in portraying the Kings in the most sacred parts of the Church i.e. the Apse.

Thus one hopes at the end that more researches and studies could shed light on the early Christian history of Nobatia, for it is still ambiguous in many parts especially from the theological point of view where the Church swung sometimes between the Orthodox faith and the Melkite one.

\section{Bibliography}

1- Adam, L., \& Grzegorz, O., (2017), “An Unexpected Guest in the Church of Sonqi Tino," Dotawo: A Journal of Nubian Studies 4, pp. 257-268.

2-Adams, W. Y., (1991a), "Nobatia”, Coptic Encyclopedia 5, pp. 1797-1798.

3- Adams, W. Y., (1991b), 'Nubian Church Art”, Coptic Encyclopedia 6, pp. 1181-1182.

4-Donadoni, S., (1975), "Les Graffiti de l’Eglise de Sonqi Tino”, In: Michałowski, K. (ed.) Nubie, Récentes recherches, Warsaw, pp. 31- 39. 
5- Grossmann, P., (1991a), "Nubian Christian Architecture", Coptic Encyclopedia 6, pp.1807-1811.

6- Grossmann, P., (1991b), "Church architecture in Egypt", Coptic Encyclopedia 2, pp. $552-555$.

7- Helm, M. van der, (1985), "Some Iconographical Remarks on St. Michael in Sonqi Tino," Nubian Letters 4, pp. 26-27.

8- Łajtar, A. \& Zielińska, D., (2016), "The Northern Pastophorium of Nubian Churches: Ideology and Function (on the basis of inscriptions and paintings)", In: Łajtar, A. Obłuski, A., Zych I., (ed.) Aegyptus et Nubia Christiana, The Włodzimierz Godlewski Jubilee Volume on the Occasion of his $70^{\text {th }}$ Birthday, Polish Centre of Mediterranean Archaeology, University of Warsaw, pp. $435-457$.

9- Martens- Czarnecka, M., (2007), "Some Remarks on Iconography of Rulers and Archangels in Nubian Painting", Etudes et Travaux 31, pp.92-107.

10- Martens- Czarnecka, M., (2015), "The Christian Nubia and the Arabs", Studia Ceranea 5, pp. 249-265.

11- McGuckin, John A., (2004), St. Cyril of Alexandria: The Christological Controversy: Its History, Theology, and Texts. St. Vladimir's Seminary Press Crestwood, New York. 12- Michalowski, K., (1966), Faras, Centre Artistique de la Nubie Chrétienne, Leiden.

13- Michalowski, K., (1974), Faras, Warsaw.

14- Michalowski, K. \& Gerster, G., (1967), Faras, die Kathedrale aus dem Wüstensand, Zurich and Cologne.

15- Obluski, A., (2016), "Nobadian and Makurian Church Architecture. Qasr el-Wizz, a case study", In: Łajtar, A. Obłuski, A., Zych I., (ed.) Aegyptus et Nubia Christiana. The Wtodzimierz Godlewski Jubilee Volume on the Occasion of his 70th Birthday, Polish Centre of Mediterranean Archaeology, University of Warsaw, pp. 481-512.

16- Obluski, A., (2019), “The Monasteries and Monks of Nubia”, Journal of Juristic Papyrology 36, pp. 7-114. 


\section{JOURNAL OF THE FACULTY OF ARCHAEOLOGY -VOLUME 24 -2021}

17-Salah El-Din, H., (2018), “An Ostracon Related to Archangel Michael's Cult in Upper Egypt", Scrinium 14, pp. 369 - 372.

18- Stewart, A. C., (2015), The Gnomai of the Council of Nicaea. Critical Text with Translation, Introduction and Commentary, Piscataway, NJ:Gorgias Press.

19- Tsakos, A., (2016), "Religious Literacy in Greek from the Christian Monastery at

Qasr el Wizz, Lower Nubia,” In: Sansaridou-Hendrickx, T., \& Hendrickx, B., (ed.) Proceedings of the International Conference on Greco-African and Afro-Byzantine Studies at the University of Johannesburg (27 October-1 November 2014), Johannesburg, pp. 220-230.

20- Tycner-Wolicka, M., (2013), "Fundacja Konstantynopola 8 listopada 324 roku i jej chrześcijańskiej konotacje," Late Antiquity - Studies in Source Criticism 12, pp. 43-73.

21-Vantini, G., (1970), The Excavations at Faras: A Contribution to the History of Christian Nubia, Bologna.

22- Vasiliev, A. A., (1952), The Byzantine Empire 324-1453, Madison.

23- ZieliŃska, D., (2012), "The Painted Decoration of the Church at Sonqi Tino in the Context of the Iconographical Program of Nubian Churches", Scienze dell'Antichità 18, pp. 593-500.

24-ZieliŃska, D., (2014), “The Iconography of Power- The Power of Iconography: the Nubian Royal Ideology and its Expression in Wall Painting", In the Fourth Cataract and Beyond: Proceedings of the $12^{\text {th }}$ International Conference for Nubian Studies, PeetersLeuven, pp.943-949. 
Figures

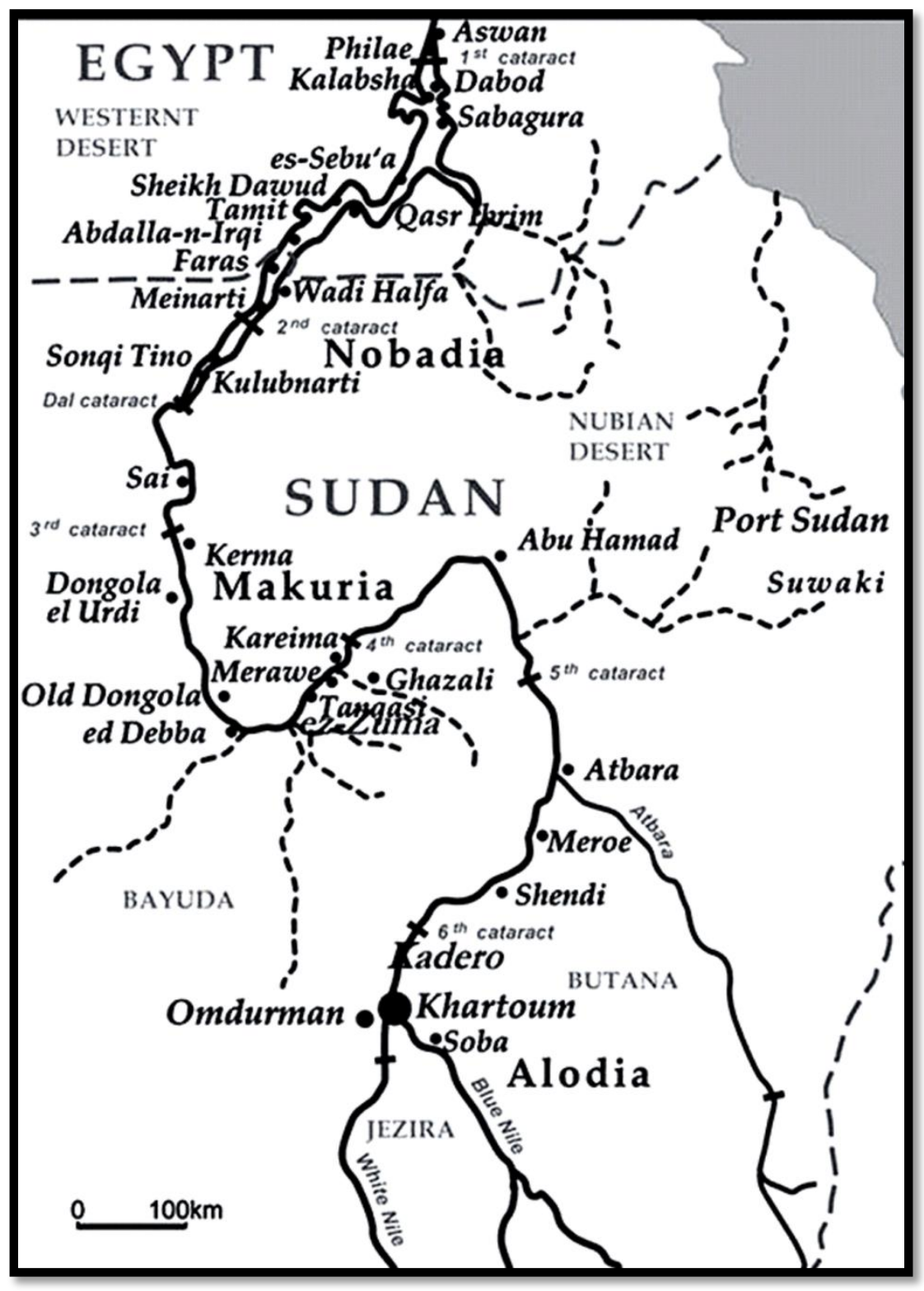

Figure 1

The Nubian kingdoms in the Middle Nile Valley 


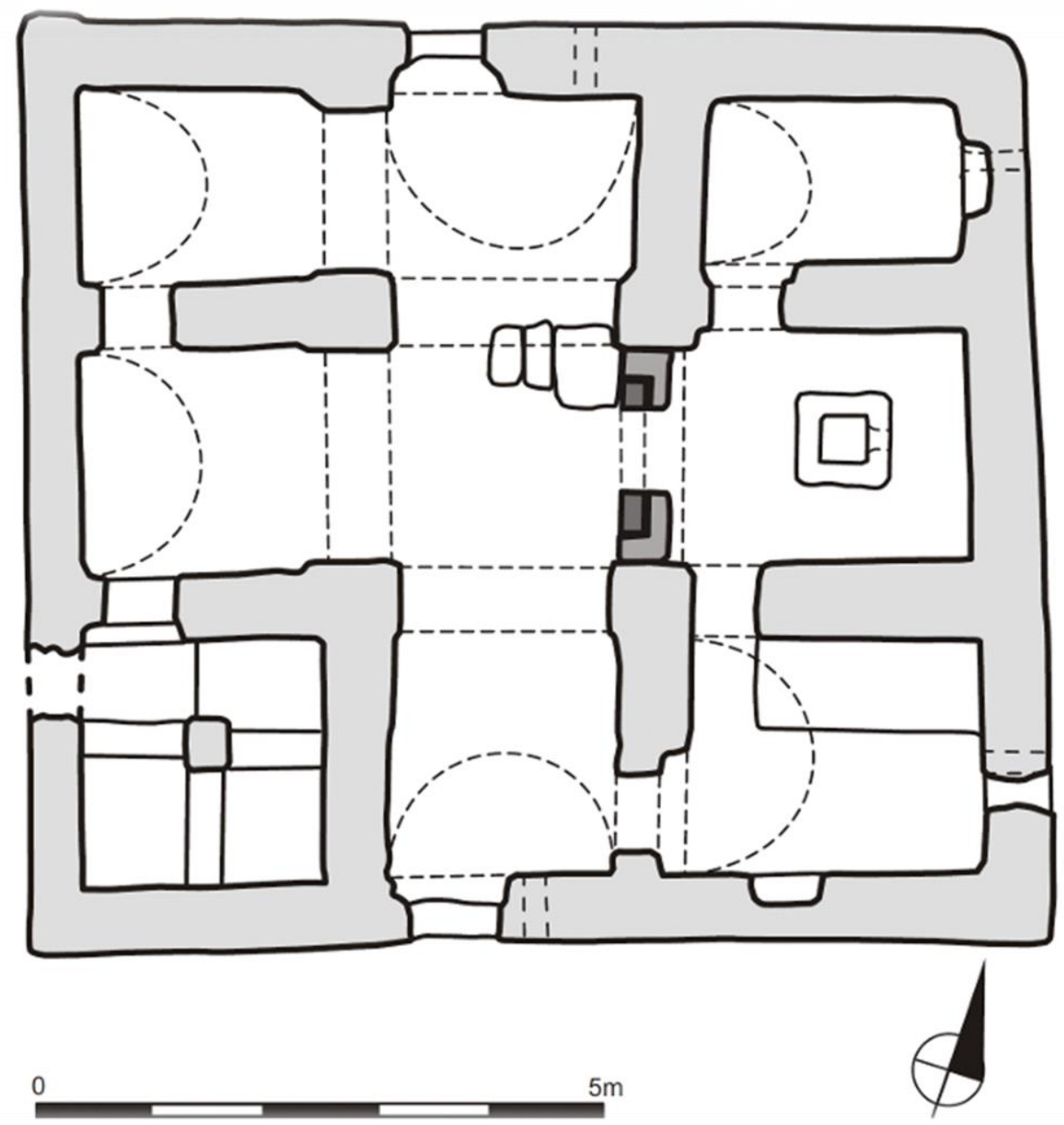

Figure 2

Sonqi Tino Church

(Thanks to Professor Artur Obluski who provided me with this plan) 


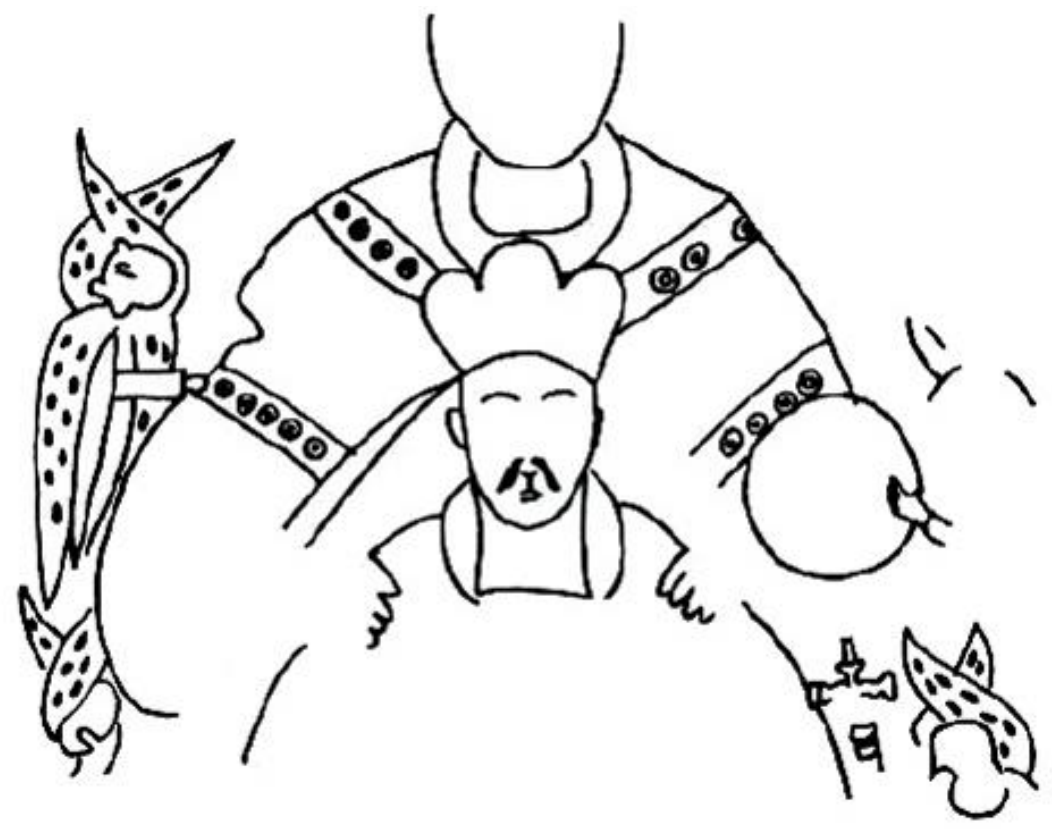

Figure 3

The archangel Michael protects a Nubian royal person

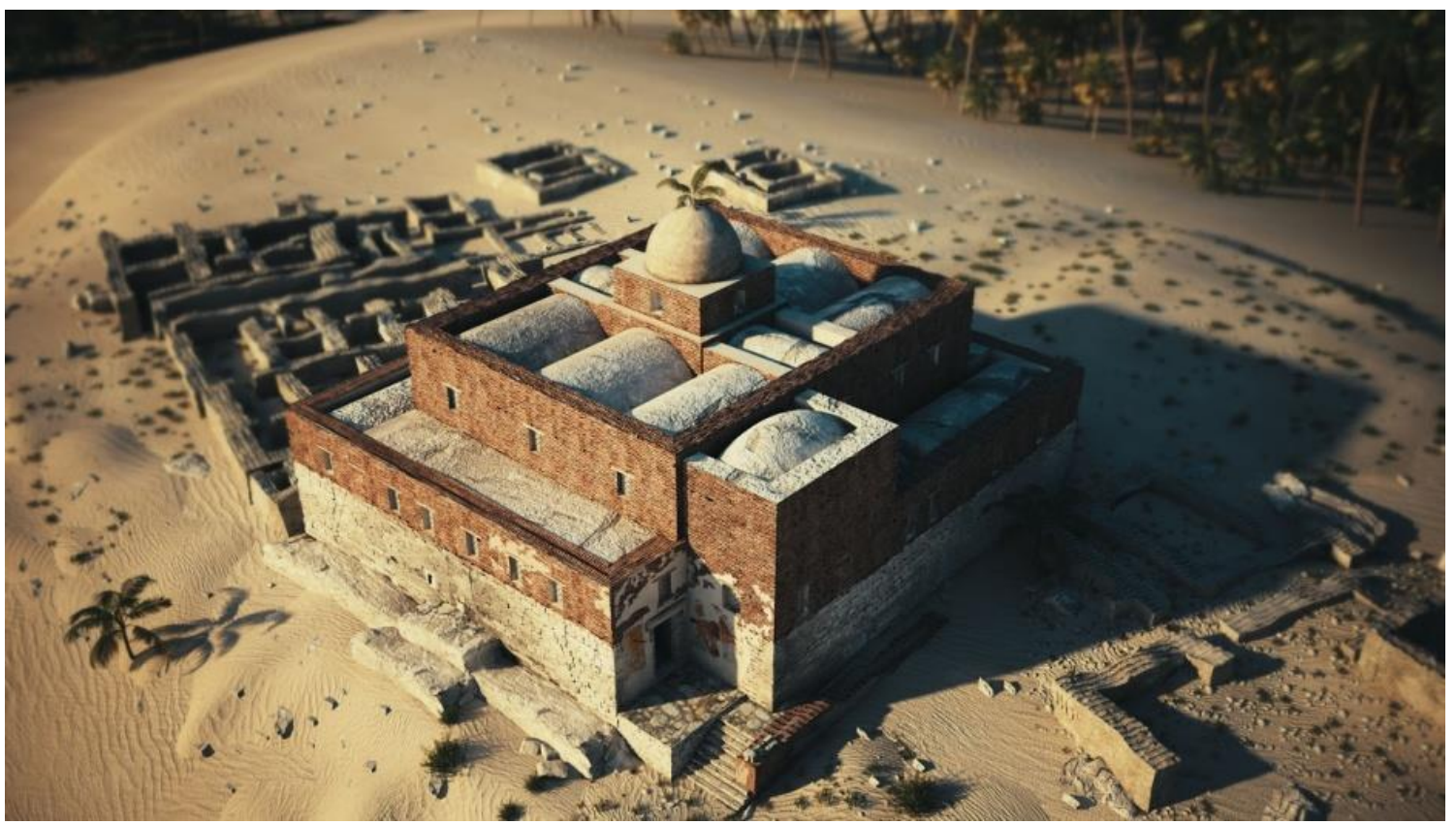

Figure 4

View of the Faras Cathedral from the Southwest

https://artsandculture.google.com/exhibit/the-faras-gallery-treasures-from-theflooded-desert/zAKSFOp2 BDeIg 


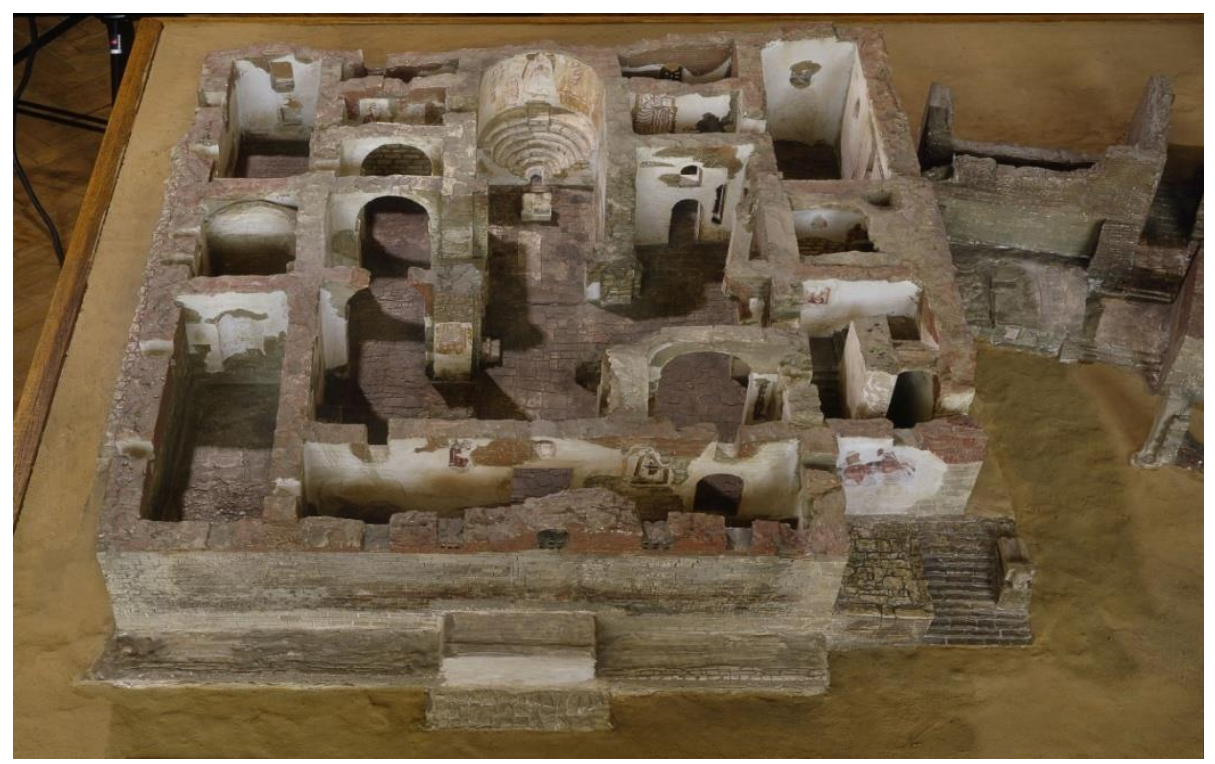

Figure 5

Faras Cathedral model made by Zbigniew Doliński, Polish National Museum, Warsaw

https://www.ancient.eu/uploads/images/10377.jpg?v=1599147904

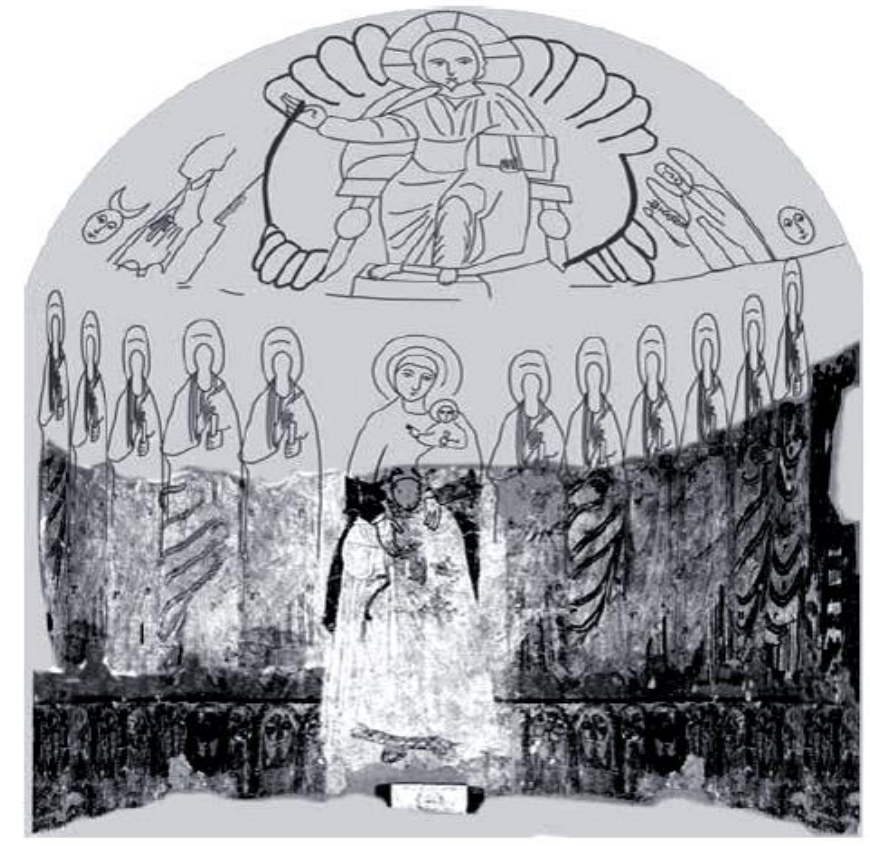

Figure 6

The "Two Zones" apse of Faras Cathedral 


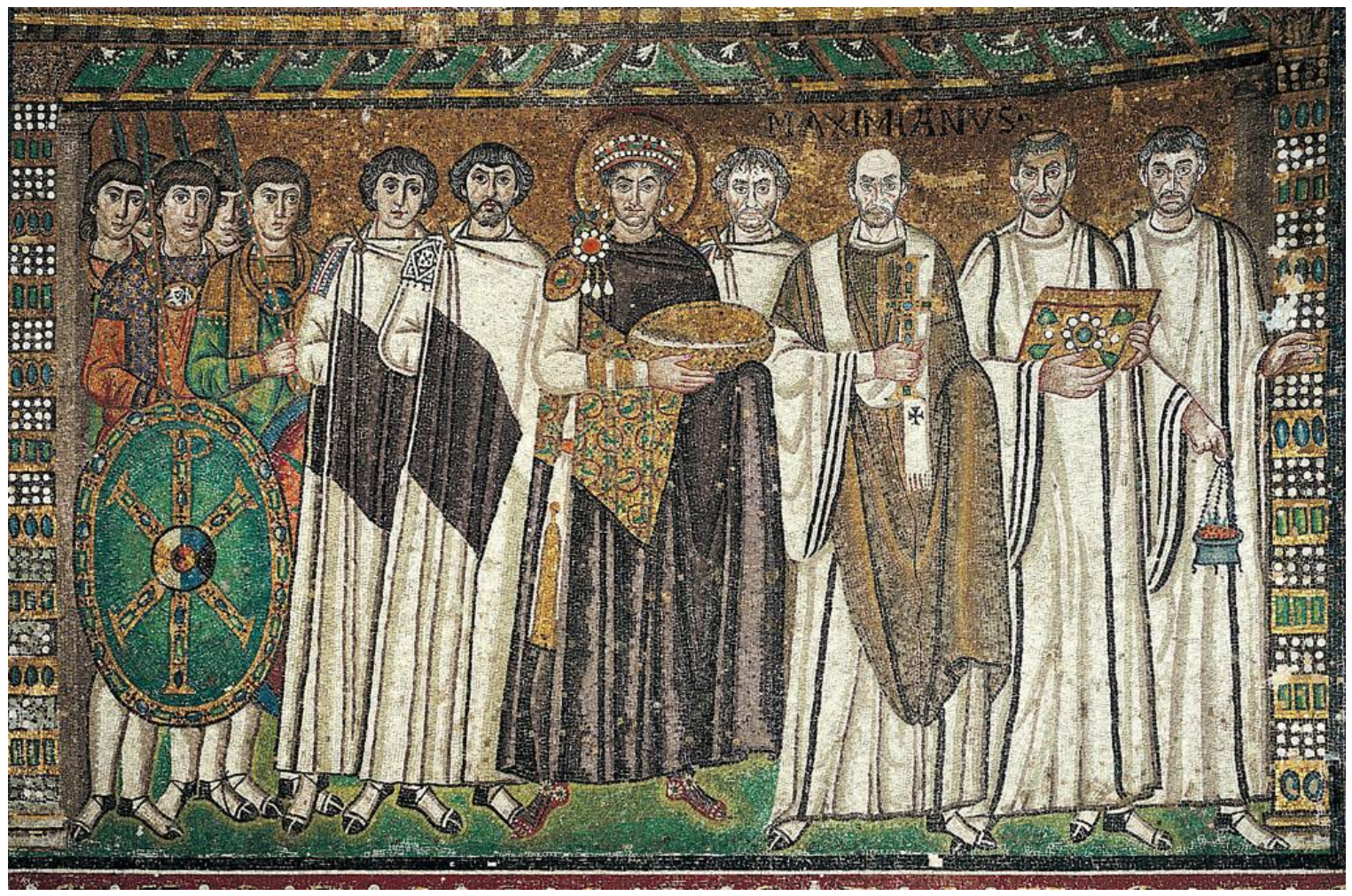

Figure 7

The Apse of the San Vitale Church in Ravenna

http://employees.oneonta.edu/farberas/arth/images/109images/early_christian/san_v itale/justinian.jpg 